\title{
Challenging Lumen-Apposing Metal Stent Removal after Successful Drainage of a Pancreatic Pseudocyst
}

\author{
Athanasios D. Sioulas ${ }^{a}$ Konstantina Papadaki ${ }^{a}$ Dimitrios Schizas ${ }^{b}$ \\ Ilias Scotiniotis ${ }^{\mathrm{a}}$ \\ ${ }^{a}$ Department of Gastroenterology, Hygeia Hospital, Athens, Greece; ${ }^{b} 1$ st Department of Surgery, National and \\ Kapodistrian University of Athens, Laikon Hospital, Athens, Greece
}

Keywords

Complications · Pancreas · Pseudocyst drainage

\section{Remoção desafiante de prótese metálica de aposição luminal após drenagem com sucesso de pseudoquisto pancreático}

\section{Palavras Chave}

Complicações · Pâncreas · Drenagem de pseudoquisto

A 45 -year-old man with a symptomatic 14 -cm-sized pancreatic body pseudocyst following alcohol-induced acute pancreatitis 19 months earlier was treated with placement of a lumen-apposing metal stent. The stent (Hot Axios, Boston Scientific Corporation, Marlborough, MA, USA) had a length of $1 \mathrm{~cm}$ and a diameter of $10 \mathrm{~mm}$ and was inserted under endosonographic guidance. The patient experienced immediate relief of symptoms and imaging studies confirmed the complete resolution of the pseudocyst. Endoscopy 11 weeks later revealed epithelial overgrowth of its gastric flange (Fig. 1), though the stent was visible within the gastrocystic fistula (Fig. 2). Stent removal by means of a rat-tooth forceps was performed, but necessitated significant maneuvering in order the gastric flange to be released. No procedure-related complications were encountered. Thus, the recommended 8 -week period for lumen-apposing stent removal should not be significantly exceeded, to prevent a "buried stent" syndrome secondary to epithelial overgrowth at its gastric end $[1-3]$.

\section{Disclosure Statement}

All authors confirm that there is no conflict regarding this publication.

\section{KARGER}

E-Mail karger@karger.com www.karger.com/pjg
(C) 2018 Sociedade Portuguesa de Gastrenterologia Published by S. Karger AG, Basel

Karcer

Open access

This article is licensed under the Creative Commons AttributionNonCommercial-NoDerivatives 4.0 International License (CC BYNC-ND) (http://www.karger.com/Services/OpenAccessLicense) Usage and distribution for commercial purposes as well as any distribution of modified material requires written permission.
Dr. Athanasios D. Sioulas

Department of Gastroenterology, Hygeia Hospital

4 Erythrou Stavrou Street and Kifissias Avenue

GR-15123 Athens (Greece)

E-Mail athsioulas@yahoo.gr 


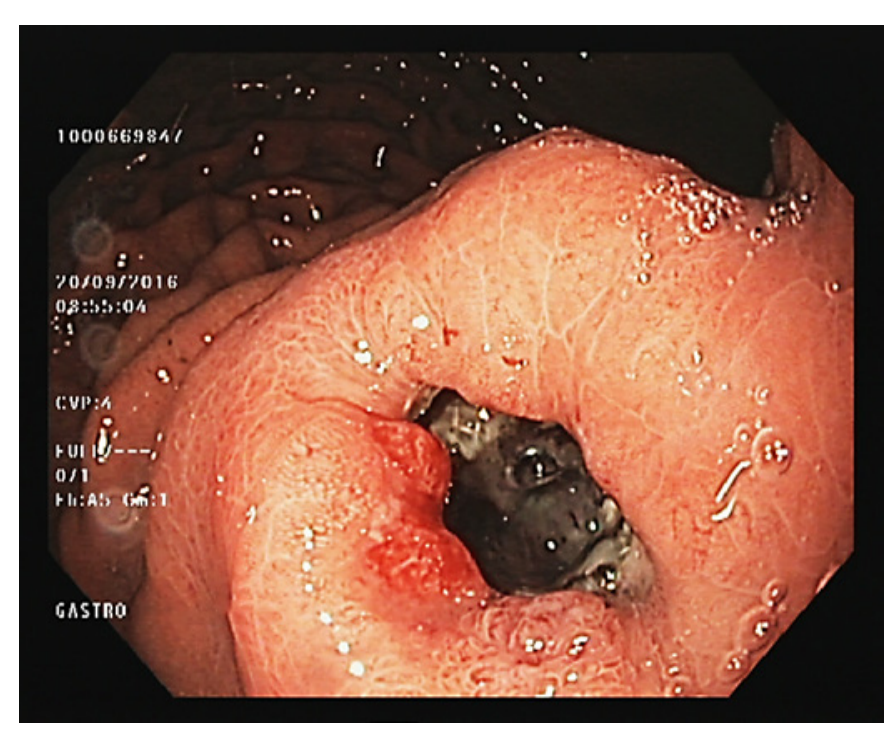

Fig. 1. Epithelialized stent prior to removal.

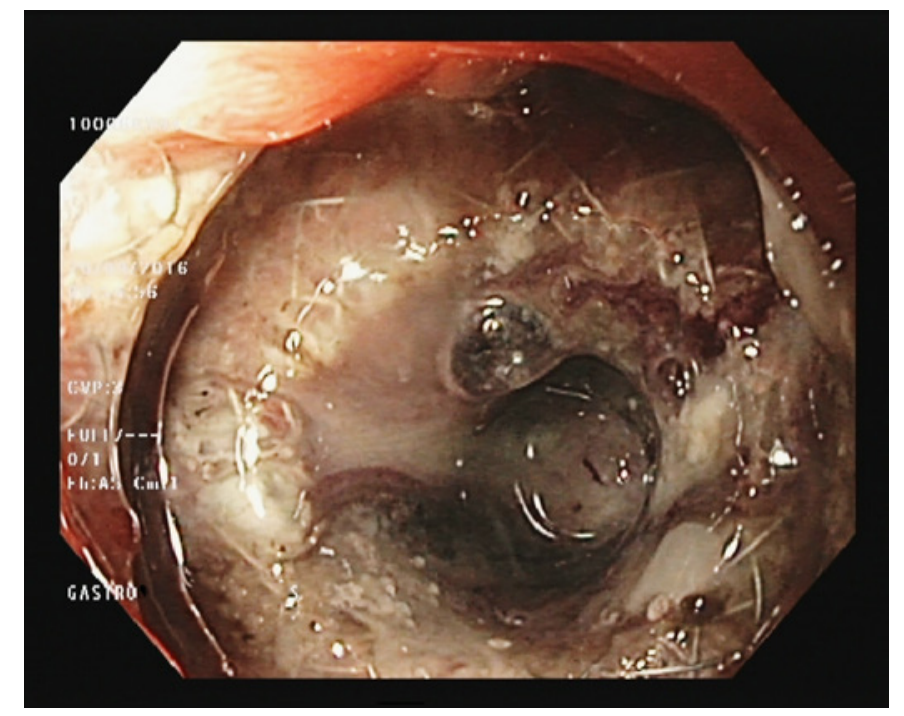

Fig. 2. Stent dislocated into the gastrocystic fistula.

\author{
References
}

1 Bang JY, Hasan M, Navaneethan U, Hawes R, Varadarajulu S: Lumen-apposing metal stents (LAMS) for pancreatic fluid collection (PFC) drainage: may not be business as usual. Gut 2017;66:2054-2056.
2 Rodrigues-Pinto E, Grimm IS, Baron TH: Removal of buried gastroduodenal stents after drainage of pancreatic fluid collections: Silence of the LAMS (with video). Gastrointest Endosc 2016;83:853-854.

3 Patil R, Ona MA, Papafragkakis C, Anand S, Duddempudi S: Endoscopic ultrasoundguided placement of AXIOS stent for drainage of pancreatic fluid collections. Ann Gastroenterol 2016;29:168-173. 